\title{
NATIVE RIGHTS AND LAW IN AN AGE OF PROTEST*
}

\author{
PETER A. CUMMING**
}

\begin{abstract}
Professor Cumming's article analyzes the aboriginal rights problem in Canada. The author lays the groundwork for his article by a discussion of the historical origin and legal status of aboriginal rights. After various comments on the Federal Government's Indian policy (both past and present), the author takes an in-depth look at the position and attitudes of the three types of native peoples affected by the question of aboriginal rights-status Indians, Metis, and Eskimo. In concluding, Professor Cumming examines the Alaska Native Claims Settlement Act, and submits that the Act is an example of truly imaginative social policy in attempting to find a fair and equitable solution to the aboriginal rights problem in that State. The author states that a native problem exists in Canada, and submits that a legislative solution recognizing aboriginal rights is, without qualification, preferable to the judicial type of solution which we appear to be headed towards in Canada. This article is based upon a paper prepared for a symposium associated with the official opening of the new Law Centre of The University of Alberta, May 4 and 5, 1972. Significant developments have taken place in the subject area since this paper was given. However, this does not affect the validity of the discussion and arguments set forth in the paper. The interested reader is also advised to refer to the preceding article, by Lester and Parker, on the British Common Law concepts of aboriginal rights and its particular application in Australia.
\end{abstract}

\section{INTRODUCTION}

The issue of aboriginal rights is both esoteric and complex. There are many misconceptions. There is a lack of meaningful Government policy on the question. The problems of common concern to native peoples and non-natives North of ' 60 cannot be rationally dealt with unless and until there is a fair and equitable solution to claims based upon aboriginal rights.

Aboriginal claims can be asserted on both moral and legal grounds. The settlement of native claims also offers a unique opportunity for accomplishing needed social change in northern Canada. In other words, apart from a legal or moral basis, a settlement of aboriginal claims can and should be made simply on a pragmatic basis. Such a settlement can be justified as a basis for providing an entirely new policy in respect to native peoples. In economic terms, such a policy would be cheaper than the present one, and in social and human terms a new policy would be an immense improvement. All Canadians, native and non-native alike, would benefit from an equitable settlement of this critical issue. Moreover, the settlement of aboriginal claims is related directly to important socio-cultural questions and to the whole matter of land use and environmental protection. These assertions are the thesis of this paper which focuses upon the question of aboriginal rights and claims North of ' 60 .

\footnotetext{
- The writer emphasizes that he speaks only for himself as an interested Canadian and not as the representative of any native person or group. The writer acknowledges with appreciation the assistance provided by Kevin Aalto, a second year law student at Osgoode Hall Law School, in the preparation of this paper.

*๑Professor of Law, Osgoode Hall Law School, York University, Toronto.
} 


\section{WHAT ARE ABORIGINAL RIGHTS?- THE HISTORICAL AND LEGAL POSITION}

Aboriginal rights are those property rights which native peoples retain as a result of their original use and occupancy of lands. ${ }^{1}$ These property rights have always been recognized by English and Canadian law. The theory of aboriginal rights originated at least as early as the 17 th century as part of international law, as viewed by Great Britain, Spain, The Netherlands, and perhaps some of the other colonizing nations. The basic notion was that, although a discovering nation took sovereignty to the lands in question, the native peoples retained property rights. At law these property rights appear to be complete except for two incidents peculiar to aboriginal land rights. First, aboriginal title can only be surrendered to the Crown. That is, the native peoples cannot make a private sale, as the Crown is the only entity which can extinguish the title, either by purchase or conquest (expropriation). Secondly, the concept of aboriginal title is one of communal rather than individual ownership.

Great Britain fully recognized aboriginal rights during the process of colonization of North America. The Royal Proclamation of 1763, issued following the British conquest of the French in North America, is one of the first official documents to clearly articulate this concept. It is an important addition to the law of aboriginal rights in Canada because it is a basic constitutional document in Canada's history; because it is a clear statement of Canadian law on the subject; and, because subsequent to 1763 the procedures set forth in the proclamation for the extinguishment of native claims were followed in obtaining more lands to meet the pressure of colonization. The Royal Proclamation, when issued, applied to all lands of British North America including those of the Hudson's Bay Company and, it is arguable, was a statement of policy and law in respect to lands which were then undiscovered, but later would come under British sovereignty. ${ }^{2}$

The basic intent of the Royal Proclamation was to create a large area of land "reserved" to the Indians as their hunting grounds and to proscribe white settlement there. As pressures for land for white settlement became acute, the Proclamation provided that the lands in "Indian Country" could be sold, but only to the Crown. That this procedure was closely followed is evidenced by the many treaties entered into between the Crown and the Indians in an extensive treaty-making system lasting until 1923 and covering almost all of Ontario and much of the West. The fact, too, that Canada's native peoples were to become the constitutional responsibility of the Federal Government by virute of s. 91(24) of the British North America Act is a further manifestation of the policy expressed in the Royal Proclamation toward aboriginal rights.

It must be emphasized, however, that the recognition of aboriginal rights in Canada preceded the Royal Proclamation and that it is not the exclusive source of these rights in Canada. One example of this assertion is the fact that the Hudson's Bay Company concluded a treaty with the Indians around Rupert's River as early as $1668 .^{3}$ Throughout Canada's

\footnotetext{
t For an authoritative treatment of the law of native rights in Canada see Cumming and Mickenberg et al., Native Rights in Canada (2nd. ed., 1972), upon which much of this paper is based.

2 See also the discussion in Native Rights, supra, n. 1 at $23-30$.

Id. at $30-35$.
} 
history there is a clear recognition of aboriginal rights and indications that these rights could not be interfered with in the absence of consultation between the native peoples and the Federal Government, with compensation being paid for the extinguishment of these rights. The following are examples of legislation, common law, and executive acts which confirm this assertion:-

1. 1869-70-The purchase of the Hudson's Bay Company's territories and the acquisition of the North-Western Territory. The Federal Government accepted responsibility for any claims of the Indians to compensation for land in Rupert's Land and the North-Western Territory. ${ }^{4}$

2. 1870-The Manitoba Act granted land to settle the Métis' aboriginal claims. ${ }^{5}$

3. 1871-1930-The numbered treaties and their adhesions speak of the Indians conveying land to the Crown. As the Order-in-Council for Treaty No. 10 demonstrates, the treaty-making was done with a concept of aboriginal title clearly in mind: 6

On a report dated 12th July, 1906 from the Superintendent General of Indian Affairs, stating that the aboriginal title has not been extinguished in the greater portion of that part of the Province of Saskatchewan which lies north of the 54th parallel of latitude and in a small adjoining area in Alberta ... that it is in the public interest that the whole of the territory included within the boundaries of the Province of Saskatchewan and Alberta should be relieved of the claims of the aborigines; and that $\$ 12,000$ has been included in the estimates for expenses in the making of a treaty with Indians and in settling the claims of the half-breeds and for paying the usual gratuities to the Indians.

4. 1872-The first Dominion Act dealing with the sale of Crown land. Section 42 stated: ${ }^{7}$

None of the provisions of this Act respecting the settlement of Agricultural lands, or the lease of Timber lands, or the purchase and sale of Mineral lands, shall be held to apply to territory the Indian title to which shall not at the time have been extinguished.

This provision remained in the various Dominion Lands Acts until 1908.

5. 1875-The Federal Government disallowed "An Act to Amend and Consolidate the Laws Affecting Crown Lands in British Columbia" stating: ${ }^{8}$

There is not a shadow of doubt, that from the earliest times, England has always felt it imperative to meet the Indians in council, and to obtain surrenders of tracts of Canada, as from time to time such were required for the purposes of settlements.

As authority the Deputy Minister of Justice cites the 40th article of The Articles of Capitulation of Montreal and the Royal Proclamation of $1763 .^{9}$ 6. 1876-Speech of Governor-General Dufferin in Victoria strongly upholding the concept of Indian title and criticizing the British Columbia Government. ${ }^{10}$

7. 1879-The Dominion Lands Act authorized the granting of land in the Northwest Territories to satisfy ". . . any claims existing in connec-

\footnotetext{
- The deed of surrender is reprinted in R.S.C. 1970, Appendices at 257.77.

s.C. 1870, c. $3,8.31$.

- Treaty No. 10 and Reports of Commissioners (1966) at 3.

TS.C. 1872, c. 23.

- W. E. Hodgins, Dominion and Provincial Legislation, 1867-1895 (1896).

IId.

to The speech may be found in Stewart, Canada under the Administration of the Earl of Dufferin 491-93 (1897).
} 
tion with the extinguishment of the Indian title, preferred by halfbreeds. ...."11

8. 1888-In the case of St. Catherine's Milling and Lumber Co. v. The Queen $^{12}$ the Federal Government argued that it obtained a full title to land from the Indians by Treaty No. 3.

9. The Federal-Provincial Agreements which followed the decision in the St. Catherine's case sometimes employed the following "whereas" clause (taken from the 1924 Ontario Agreement): 13

Whereas from time to time treaties have been made with the Indians for the surrender for various considerations of their personal and usufructuary rights to territories now included in the Province of Ontario...

10. 1889-The Federal Government disallowed the Northwest Territories Game Ordinance because it violated Indian treaty hunting rights.14

11. 1912-In the boundaries extension legislation for both Ontario and Quebec, the Federal Government made a special provision requiring treaties with the Indians. ${ }^{15}$

12. 1930-British North America Act. This act transferred the ownership of natural resources to the prairie provinces. In each of the provinces the Indians are protected in their right: ${ }^{16}$

... of hunting, trapping and fishing game and fish for food at all seasons of the year on all unoccupied Crown lands and on any other lands to which the said Indians may have a right of access.

13. 1946-The evidence of M. R. A. Hoey, Director of the Indian Affairs Branch, May 30, 1946, before the Joint Committee of the Senate and House of Commons: ${ }^{17}$

From the time of the first British settlement in New England, the title of the Indians to lands occupied by them was conceded and compensation was made to them for the surrender of their hunting grounds . . . this rule, which was confirmed by the Royal Proclamation of October 7, 1763, is still adhered to.

14. 1946-The evidence of Mr. T. R. L. MacInnes, Secretary, Indian Affairs Branch, June 4, 1946: ${ }^{18}$

Now it remained for the British to recognize an Indian interest in the soil to be extinguished only by bilateral agreement for a consideration. That practice arose very early in the contracts between the British settlers and the aborigines in North America, and it developed into the treaty system which has been the basis of Indian policy both in British North America and continuing on after the revolutionary war in the United States.

15. 1966-The Canadian Indian, a pamphlet published by the Department of Indian Affairs, states: ${ }^{19}$

Early in the settlement of North America, the British recognized Indian title or interests in the soil to be parted with or extinguished by agreement with the Indians and then only to the Crown.

\footnotetext{
II S. C. 1879 , c. $31,8.125(e)$.

12 (1889) 14 App. Cas. 46 at 54.

13 S.C. 1924 , c. 48.

it Reprinted in S.C. 1891, at 1xi.

15 S.C. 1912, c. 40, 8. 2(a) (Ontario); S.C. 1912, c. 45, s. 2(c) (Quebec).

16 R.S.C. 1970, Appendices, at 371, 380-81, and 388-89.

17 Minute No. 1, at 31.

18 Joint Committee of the Senate and House of Commons, Minute No. 2, at 54.

10 Dept. of Indian Affairs and Northern Development, The Canadian Indian 3 (1966).
} 
16. 1971-The Dorion Commission Report expressly recognizes aboriginal rights, urges an expansive view of the content of aboriginal title and acknowledges the need to compensate native peoples for the extinguishment of their native rights. ${ }^{20}$

The present Federal Government, however, in a dramatic departure from Canadian history and law, has expressly stated that aboriginal rights, apart from treaty rights, will no longer be recognized.21 The native peoples, therefore, in seeking redress for the loss of their lands and traditional rights have had to turn to the only forum availablethe courts. The Nishga Tribe of British Columbia, for example, began an action for a declaration that their aboriginal rights have never been extinguished in respect of a large land area in the Nass Valley of British Columbia. The British Columbia Court of Appeal, in its decision, ${ }^{22}$ has declared that the Royal Proclamation did not apply to British Columbia and further, that there can be no judicial recognition of aboriginal rights in the absence of legislative or executive "recognition" of such title. The Nishga Tribe appealed to the Supreme Court of Canada and the appeal was heard in October, 1971, but no decision has yet been given. The decision in the Calder case will be the most important decision in the history of aboriginal rights in Canada.

\section{WHO ARE THE NATIVE PEOPLES AFFECTED?}

Of the approximately 500,000 native peoples in Canada only about 250,000 are "status Indians" entitled to registration under the Indian Act and only about one-half of this group (i.e. 125,000) are treaty Indians. ${ }^{23}$ The other 250,000 native peoples include non-status Indians, Métis people, and some 16,500 Inuit. Land claims of the 125,000 of Canada's native peoples who are registered members under the Indian Act of those Indian nations signing treaties are the only class of claims the present Federal Government has decided to continue to recognize even though, as has been indicated, the entire treaty-making is simply a manifestation of governmental recognition of aboriginal rights generally. Aboriginal rights are not created by treaty, and the treaties themselves make this clear. They are simply a recognition that the rights do exist and that they have been extinguished in consideration for compensation paid. (This assumes, of course, that the written language of a given treaty truly represents the actual agreement between the Indians and the Crown.) Aboriginal claims can be asserted for a large percentage of the 375,000 native peoples who are not treaty Indians, based upon the historical development of Canadian law and policy on the subject.

In the Northwest Territories there are approximately 6,000 Indian people who come within Treaties Nos. 8 and 11. However, the 2,600 non-treaty status Indians of the Yukon Territory, the Métis people of the north, apart perhaps from those who are descendants of persons receiving land grants or money scrip in settlement of their aboriginal rights, and the 11,200 Inuit, still have claims based upon the law of aboriginal rights. Moreover, the Indian people who come within Treaties Nos. 8

20 Rapport de la Commission d'Etude sur l'Integrite du Territoire du Quebec: le Domaine Indien, Vol. 4.1 at 389-97 (Quebec 1971).

21 See the excerpts from a speech by Prime Minister Trudeau on August 8, 1969, in Vancouver, British Columbia reprinted in Native Rights in Canada, supra, n. 1. Appendix VI.

32 Calder v. Attorney General (1971) 13 D.L.R. (3d) 64, (1970) 74 W.W.R. 481 (B.C.C.A.).

23 The figures used in this section are only approximate and can be found in D. Fidler, Red Power in Canada (1970); and The Canada Year Book 1970-71, 250-53 (1971). 
and 11 should continue to have claims based upon the law of aboriginal rights, to the extent that their rights were not truly surrendered in the treaty-making process.

\section{A CENTURY OF PATERNALISM-THE NON-NATIVE'S ROLE IN INDIAN SOCIETY-THE POLICY OF ASSIMILATION}

The Indian Act is the single, yet very significant, piece of legislation which Parliament has chosen to enact pursuant to its authority under s. 91(24) of the British North America Act. The Indian Act regulates almost totally the life-style, both as individuals and communities, of those 250,000 status Indians on reserves. The misguided policy behind this legislation is twofold: first, the Indian is viewed as incapable of managing his own affairs, and therefore benevolent paternalism is essential; and, secondly, the values, culture, and life-style of native persons are looked upon as inferior to those of non-native society. It is apparent, therefore, that the Indian Act serves as a mechanism to assimilate the native person into non-native society.

The effect of the Indian Act upon four generations has been to virtually destroy Indian culture and identity. The colonial administrative and legal framework on the reserve has rigorously imposed the nonnative at every level of significant community and individual decisionmaking, such as in respect to local government and the use of monies or the use of lands. This has resulted in the virtual destruction of the Indian people. They have been deprived, unlike any other group of Canadians, of the opportunity of learning by self-experience and initiative. They have been placed in the proverbial 1984 welfare state with consequential destruction of pride and, ultimately, self-identity. Moreover, the paternalism of the "great white father" has not been beneficent. Native people have traditionally received a good deal less than non-natives from government spending. In other words, those who have needed more have received less. ${ }^{24}$ This is compounded by a waste in the use of resources in the delivery of services through a large government bureaucracy. ${ }^{25}$

Finally, the policy of assimilation has resulted in a destruction of Indian self-identity. The ultimate paradox is two-fold in nature. First, the vertical federal structure within the Department of Indian Affairs through the Indian Act has resulted in isolation from horizontal contact with provincial society. Secondly, the destructiveness of the Indian Act has resulted in a wide educational, economic, and social gap between the Indian and non-Indian.

\section{THE TREATY-MAKING PROCESS}

It has been emphasized that the land cession treaties, of which the major ones are the numbered treaties of western Canada entered into between the Crown and Indian Nations between 1871 and 1923, are simply an exemplification of the general law of aboriginal rights. The question therefore arises as to what is their status in law, apart from being a basis of settlement of aboriginal rights.

The term "treaty" suggests three notions-a contract or conveyance,

24 Infra, Appendix, Part I

2s Infra, Appendix, Part II 
quasi-legislation and international law. Although judicial interpretation of treaties by Canadian courts is sparse, the weight of judicial authority would indicate that the treaties are simply in the nature of ordinary contracts under Canadian law. ${ }^{26}$ Thus, the competence of Parliament under s. 91(24) of the British North America Act to legislate in respect to "Indians and lands reserved for Indians" provides Parliament with the power to abrogate treaties. This legislative competence further allows Parliament to abrogate, that is, expropriate, aboriginal rights apart from treaty.

Moreover, the term "Indians" in s. 91(24) has been held to mean "aboriginals" generally. ${ }^{27}$ Consequently, it is important to realize three points. First, aboriginal and treaty rights inure to individuals by virtue of the fact that they are native people, and thus the mere fact that an individual native person (i.e. Inuit and Métis) may be excluded from the Indian Act does not affect his native rights. Native rights are derived from one's racial and cultural origins, not from the provisions of the Indian Act. Secondly, Parliament has constitutional supremacy to do what it chooses-to regulate, deny, expand or settle claims based upon aboriginal rights. Finally, the test of a native person's qualifications for any settlement of aboriginal claims must be based simply upon his racial and cultural origins.

The treaty provisions generally include land rights, hunting and fishing rights, annuity payments, and the right to education, as well as miscellaneous benefits, such as monies for ammunition and twine.

\section{HUNTING AND FISHING RIGHTS}

It is essential to speak briefly about hunting and fishing rights because of their importance to native people.

Hunting and fishing rights over unoccupied Crown lands were guaranteed by many treaties. The Crown expressly promised in making treaty that this right would remain "as long as the sun rises and the water flows." 28 The emphasis placed upon the retention of hunting and fishing rights by the Indian people is evidenced in the following excerpt from the Report of the Commissioners for Treaty No. 8.

Our chief difficulty was the apprehension that the hunting and fishing privileges were to be curtailed. The provision in the treaty under which ammunition and twine is to be furnished went far in the direction of quieting the fears of the Indians, for they admitted that it would be unreasonable to furnish the means of hunting and fishing so restricted as to render it impossible to make a livelihood by such pursuits. But over and above the provision, we had to solemnly assure them that only such laws as to hunting and fishing as were found necessary in order to protect the fish and fur-bearing animals would be made, and that they would be as free to hunt and fish after the treaty as they would be if they never entered into it.

Unfortunately, the Migratory Birds Convention Act ${ }^{29}$ passed in 1917, and the Fisheries $\mathrm{Act}^{30}$ passed as conservation measures because of non-

\footnotetext{
20 Attorney.General for Canada v. Attorney.General for Ontario [1897] App. Cas. 199 (P.C.); Rex v. Wesley [1932] 4 D.L.R. 774, 2 W.W.R. 337 (Alta. App. Div.).

27 Re Eskimos [1939] S.C.R. 104; Sigeareak El-53 v. The Queen (1966] S.C.R. 645, 57 D.L.R. (2d) 536.

25 See e.g., the report on the negotiations of the treaties in Morris, The Treaties of Canada with the Indians (1880); reprinted by Coles Publishing Co., Toronto, $197145-46$.

29 R.S.C. 1970 , c. M-12.

30 R.S.C. 1970, c. F-14. This Act as it was first passed in 1868 did allow the Minister to grant licences to Indians to fish for their own use for various species of fish out of season. This section, however, was dropped in the 1914 consolidation of The Act without any discussion of native fishing rights.
} 
native habits, ${ }^{31}$ have inadvertently abrogated these rights. At the time of passage of the legislation, Parliament simply forgot about aboriginal rights generally, and the guarantee through treaty of hunting and fishing rights in particular. In fact, one treaty which guaranteed traditional hunting and fishing rights was entered into after passage of the Migratory Birds Convention Act. ${ }^{32}$

Apart from the deleterious effect upon the livelihood of native peoples, this unilateral abrogation of native rights by Parliament and continuing injustice strikes at the very self-identity of native people. The adverse psychological consequences have been immense. Although the courts have been critical of Parliament's failure to redress the situation, ${ }^{33}$ and although no cost is involved in giving redress, this wrong has not yet been rectified. To continue to deny hunting and fishing rights guaranteed by treaty is to continue to repudiate the clear promises made to the Indian nations which entered into treaties. Moreover, as hunting and fishing rights are simply an incident of aboriginal rights, they should also be recognized in respect to those native peoples who have not signed treaties.

\section{THE INDIAN PEOPLE-TREATIES NOS. 8 AND 11}

In several specific areas treaty obligations on the part of the Government have not been fulfilled and remain a source of discontent to the Indian peoples. Perhaps the major area of controversy is the curtailment of hunting and fishing rights by the Migratory Birds Convention Act, already discussed.

Another important instance of non-fulfillment of treaty terms exists in relation to reserve allotments under Treaties Nos. 8 and 11.34 Treaty No. 8, signed June, 1899, purportedly ceded the greater part of northern Alberta. Treaty No. 11 was signed June 27, 1921, and purportedly ceded the Mackenzie River Country in the Northwest Territories. Treaties Nos. 8 and 11 purportedly cover that area of the Northwest Territories between the Arctic Sea and the 60th parallel latitude between the Yukon border and a line following the Coppermine River, to Lake Aylmer, then to the east end of Great Slave Lake and southeasterly to Fond du Lac at the eastern end of Lake Athabasca. A preliminary issue in respect to Treaties Nos. 8 and 11 is the validity of the written language thereof, as the research of the Indian Brotherhood of the Northwest Territories is reported to have established that the Indian people never agreed to cede their land on the basis of one square mile per family. ${ }^{35}$

However, even the purported agreement has not been honoured. Although explicitly promised by these two treaties, Indian reserve lands have yet to be allotted in the Northwest Territories. There are, according to the Indian Affairs Branch, 29 Indian settlements in the Northwest Territories which are not classified as reserves. In 1950 , s. 18(d) was added to The Territorial Lands Act enabling the federal Cabinet to: ${ }^{36}$

\footnotetext{
"It should be noted that the native peoples hunt game for subsistence and livelihood, not for sport.

32 Treaty No. 11 signed on June $27,1921$.

${ }^{33}$ See e.g., Regina v. Sikyea (1964) 43 D.L.R. (2d) 150, (1964) 46 W.W.R. 65 (N.W.T.C.A.). The courts have also noted that it is within the power of Parliament to abrogate treaty agreements with the Indians under 8.91 (24).

34 The following discussion in respect to Treaties Nos. 8 and 11 is taken in large part from Native Rights in Canada, supra, n. 1 at $126-28$ [citations omitted].

3s This information has been provided by Gerald Sutton, legal consultant to the Indian Brotherhood of the Northwest Territories. Mr. Sutton advises that the research will be published in the near future.

36 Territorial Lands Act, S.C. 14 Geo. VI, c. 22. 8. 18(d).
} 
... set apart and appropriate such areas or lands as may be necessary to enable the Government of Canada to fulfill its obligations under treaties with the Indians and to make free grants of leases for such purposes, and for any other purpose that he may consider to be conducive to the welfare of the Indians.

No action was taken on this legislation until the matter was brought before the Committee of the Privy Council on June 25, 1959. At this meeting it was noted that settlement of the land entitlement question of the Indians in the Northwest Territories (given as approximately 576,000 acres) should not be further postponed in light of the rapid development of the region. It was also noted that the Indians were divided on the question of whether to insist on their full land entitlement and therefore, might have considered re-negotiation of the treaties. To investigate these questions, a five-man Commission was established and held meetings in some 15 different Indian communities in the Northwest Territories during 1959. The alternatives presented to the Indians and discussed at the series of Commission-community meetings were:

1. They could take their land as provided in the Treaty.

2. They could ask for a portion of their land entitlement plus a cash settlement for the remaining portion.

3. In lieu of their land entitlement they could ask for mineral rights and cash.

4. A cash settlement with no land and no other rights except the rights to fish, hunt and trap as given to them in the Treaty.

5. Any other reasonable alternative that they might wish to suggest.

In the course of their presentations to the Indian community, the Commission indicated that the choice of any alternative but the taking of reserve lands as provided in the treaties would require a re-negotiation of the treaties and the consent of the Indian population of the Northwest Territories. A clear consensus on the issue did not emerge from the series of meetings. The Indians, on the basis of past experience, were extremely wary of the Government's purpose in raising the issue. The Commission's Report noted:

Generally all the bands appeared to be suspicious of the motives of the government in bringing up the matter of the unfulfilled provisions of the treaties so many years after they had been negotiated.

In its report, the Commission indicated its opinion that the Indian reserve system belonged to a past era in Canadian history and should not be instituted in the Northwest Territories. It recommended that the treaties be re-negotiated to give the Indians title to small plots of land for their homes, a lump sum of $\$ 20$ per acre for their entitlement, and an annual payment of one-half of one percent of any revenues derived by the Crown from the mineral, gas and oil reserves of that portion of the Northwest Territories ceded by Treaties Nos. 8 and 11.

Although the Indians were told by the Government in 1959 that the question of land entitlement under Treaties Nos. 8 and 11 would be settled as soon as possible, the matter appears to have remained dormant for over a decade. The matter was raised again by the Fitz-Smith Band and the Thebacha Association in July, 1968 at the consultation meeting on the Indian Act. In their brief, these two groups stated:

We Indians do not want to reopen negotiations of Treaties 8 and 11 under the Indian Act of Canada. It was signed a long time ago so we accept what they laid 
down. Therefore we have established that our people did not go back on their word, but we would like to open the question of land settlement.

The solution to the problem of land entitlements suggested by these Indian organizations was twofold:

1. Compensation for ceding our land should be worked out by preparing an estimation of all resources harvested and mined within the boundaries of Treaties 8 and 11 and placing a value on those resources (that went to benefit the white man in the south) and working out a formula which would be compensation for the Indian people ... (estimated to be $1 / 2$ of 1 percent or 75 million dollars) from the day that Treaties 8 and 11 were signed to the day and date.

2. From this date on all the revenue that the Government of Canada receives from resources harvested and mined will be turned over to the Government of the Northwest Territories.

To date, no action on either the Commission Report or the brief by the Fitz-Smith Band and Thebacha Association has been initiated by the Government. The question of land entitlement remains open as a source of friction in the relationship between the Indian peoples and the Government.

\section{THE POSITION OF THE MÉTIS PEOPLE ${ }^{37}$}

The mixed racial and cultural status of the Métis people has resulted historically in governments in Canada adopting a rather unique approach in dealing with this part of Canada's native population. While there have been departures from policy, the general attitude of governments has long been that all Metis were treated as having native rights and that these persons of mixed blood who lived as Indians were given the option to be dealt with as full-blooded Indians.

The disregard of native rights was one of the reasons for the Riel Rebellions of 1869 and 1885 . As a result, Metis land claims received formal recognition by legislation.

The first and most important piece of legislation which recognized the land claims of the Metis is the Manitoba Act: ${ }^{38}$

And whereas, it is expedient, towards the extinguishment of the Indian Title to the lands in the Province, to appropriate a portion of such ungranted lands, to the extent of one million four hundred thousand acres thereof, for the benefit of the families of the half-breed residents, it is hereby enacted ...

The clear recognition of aboriginal rights in Manitoba led the Métis population of the Northwest Territories to demand similar treatment for their land claims. These demands, which started as early as 1873 , went almost totally unheeded for several years. The influx of white settlers into the Territories during the late 1870's increased the urgency and volume of these requests for recognition and the Government finally responded to the surge of Métis petitions with a rather dilatory provision in the Dominion Lands Act of 1879. This section left to the federal cabinet the power: ${ }^{39}$

To satisfy any claims existing in connection with the extinguishment of the Indian

\footnotetext{
37 This section is abridged from Native Rights in Canada, supra, n. 1 at 201-03 [citations omitted].

38 S.C. 1870,33 Victoria, c.3, s.31.

39 S.C. 1879,42 Victoria, c. $31,8.125(e)$.
} 
title, preferred by half-breeds resident in the North-West Territories outside of the limits of Manitoba, on the fifteenth day of July, one thousand eight hundred and seventy, by granting land to such persons, to such extent and on such terms and conditions as may be deemed expedient.

The somewhat positive attitude which the Government displayed by the enactment of this provision quickly dissipated when it came to implementing its terms. It was not until the Métis threatened rebellion in 1885 that the Government finally sent scrip to the Northwest Territories.

In 1899, a Treaty Commission was established by the Government of Canada to negotiate a treaty, culminating in Treaty No. 8 , with the Indians and Métis of northern Alberta. The procedure adopted by the Department of the Interior was to send a "double Commission" to the region, one to treat with the Indians and the other "to investigate and extinguish the half-breed title." In Through the Mackenzie Basin, Charles Mair records the negotiations which preceded the signing of Treaty No. 8. His report of a speech made by Commissioner David Laird (who headed the "Indian Commission") to a large group of Indians is revealing, particularly in light of events which were to transpire some 40 years later. Mr. Laird is recorded as stating:

Commissioners Walker and Cote are here for the half-breeds, who later on, if treaty is made with you, will take down the names of half-breeds and their children, and find out if they are entitled to scrip. The reason the Government does this is because the half-breeds have Indian blood in their veins, and have claims on that account. The Government does not make treaty with them, as they live as white men do, so it gives them scrip to settle their claims at once and forever. Half-breeds living like Indians have the chance to take the treaty instead, if they wish to do so.

In 1944, the Indian Affairs branch embarked on a course which can only be described as a radical departure from the historic policy of the Canadian Government toward the Métis people. Reasoning that certain Metis in the Lesser Slave Lake area (Treaty No. 8) had white fathers or grandfathers, the Branch took about 700 of these individuals off the treaty lists and made plans to remove them from the reserves on which they had lived as Indians all of their lives.

With the urging of the late Mr. Justice Jack Sissons, then a Member of Parliament, a judicial inquiry into this matter was undertaken. The inquiry was conducted by Judge W. A. Macdonald whose Report reviews the treaty-scrip option, granted to the Métis in Treaty 8 (as well as Treaties Nos. 1 and 2) and concludes:

It would appear that whenever it became necessary or expedient to extinguish Indian rights in any specified territory, the fact that Halfbreeds also had rights by virtue of their Indian blood was invariably recognized. These rights co-existed with the rights of the Indians. It was considered advisable whenever possible to extinguish the rights of Halfbreeds and Indians by giving them compensation concurrently .... persons of mixed blood who became identified with the Indians, lived with them, spoke their language and followed the Indian way of life, were recognized as Indians. The fact that there was white blood in their veins was no bar to their admission into the Indian bands among whom they resided.

Judge Macdonald's Report undoubtedly had some impact on Indian Affairs, for most of the affected individuals were eventually returned to the treaty lists.

The legal conclusions which may be drawn from the historical review seem fairly clear. Those Métis who came under treaty are currently in the same legal position as other Indians who signed land cession treaties. Their aboriginal rights were extinguished by the treaties and 
any claim they still retain must be based on the inequitable terms of the treaties themselves.

Those Métis who received scrip or land may also have had their aboriginal rights extinguished, as the Manitoba Act and the Dominion Lands Acts of 1874 and 1878 indicate. The issuance of scrip and the circumstances and legislation accompanying it provide, however, conclusive evidence that the aboriginal rights of the Metis were recognized.

The most immediate legal effect upon those Métis who have received scrip or lands is that they are excluded from the provisions of the Indian Act. However, these Métis are still "Indians" within the meaning of the British North America Act and the Federal Government continues to have the power to legislate with respect to this group of native people.

Those Metis who have received neither scrip, nor land, nor treaty benefits, still, arguably, retain aboriginal claims which have either not been extinguished, or have been extinguished, and for which a claim for compensation is outstanding. The question of extinguishment of course turns on the historical and geographic circumstances of the particular Metis claimants.

Beyond what has been said, the Federal Government has historically chosen, in effect, to ignore the Metis people. The policy of Federal Governments, realized through the Indian Act, has been to regulate almost completely the life of the Indian on the reserve. Non-status Indians and Métis have been left as ordinary provincial citizens. Unfortunately, being racially apart from non-native society and artificially excluded from native society, the Metis have perhaps suffered even more than the status Indians, and their economic, social and educational plight is significant. ${ }^{40}$

\section{THE POSITION OF THE INUIT IN THE NORTH ${ }^{41}$}

The Inuit, who have not entered into treaties in the North, have aboriginal rights as well. The present position of the Government is to ignore these claims, and issue exploration permits without concern for Inuit land rights.

An important difference between the position of the Inuit and the position of other minority groups in southern Canada in exerting their claims for recognition by other Canadians is the vast difference in bargaining and political power, and opportunity to effectively communicate their grievances. This results from the difference in numbers (13,000 Inuit in the Northwest Territories), and the problem in communication (both as among the Inuit communities, and as between the Inuit and other Canadians) resulting from their dispersion in small settlements.

If these claims continue to be ignored, frustration, loss of pride, and ultimately loss of self-identity will result.

As has been discussed, there are two main reasons why there has been virtual destruction of Indian identity over the past century. First, the treatment of the Indian people has witnessed the continuing unilateral abrogation of Indian rights without consultation or consent. This process of abrogation of rights, as well as the taking away itself, has

\footnotetext{
10 See generally Slobodin, "Metis of the Far North" in Elliott, ed., Native Peoples 150-69, (1971).

1 The following is adapted in part from a recent brief submitted by The Inuit Tapirisat of Canada to the Prime Minister.
} 
resulted in an immense debilitation of pride and self-identity. Secondly, the Indian people have suffered a stifling and destructive paternalism.

If government policy has been to respect the rights of the Indian people as recognized historically; to make reasonable redress for the extinguishment of such rights after consultation; and, to treat the Indian people as equals with the right to exert self-initiative to the extent of other Canadians, there would not be the problems experienced today. Moreover, the cost of such concessions would have been much less than the amount of monies necessarily spent, and which continue to be spent through the various government departments for services in respect to the Indian people. This is not to suggest in any way that the Indian people receive nearly enough by way of such services, only to state forcefully that much of the inadequate expenditures for what can be regarded as "bootstrap" operations are only necessary because of the treatment suffered historically by the Indian people. The Government itself has recognized in the White Paper that this historical policy of paternalism has been a failure. Given this, it is surprising that the Government follows precisely the same policy in its relations with the Inuit in the development of the North.

The Government does not consult with the Inuit in the issuing of exploration permits for oil or minerals. There is no consideration at the time of the issuing of such permits as to the possible land or water rights or needs of the Inuit within the areas to be explored. The permits simply cover all those lands and waters upon which the Government chooses to allow exploration. There are no restrictions imposed upon the issuing of permits because of advice received from the Inuit, as the Inuit are not in any way consulted before the issuing of such permits. An extreme example of this policy is evidenced by the fact that Inuit soapstone quarries were subject to exploration permits by others until, in reaction to complaints by the Inuit, the Government caused the pertinent regulations to be reinterpreted so as to exempt soapstone quarries from exploration.

Furthermore, there is no consultation by the government with the Inuit prior to exploration as to the effects of exploration upon the ecology and the environment. The very limited consultation which does take place results simply from reaction by the Government to specific complaints after permits have been issued and exploration is underway. Two examples are dramatically illustrative of this policy. In respect to the exploration which was to come to Banks Island in the summer of 1970 , and the exploration which was to have commenced on and about Southampton Island in Hudson Bay in the summer of 1971, there was no prior consultation with the Inuit, and the only dialogue (such as it was) resulted because of opposition and demands by the Inuit after permits had been issued. This is the process, notwithstanding that the Inuit are the most knowledgeable Canadians about the environment of the North and have lived as successful environmentalists and conservationists for a very long time. There is also no consultation in respect to legislation designed to protect the environment. For example, the Inuit were not consulted in the recently developed all-important Territorial Land Use Regulations although they are the people most affected thereby. Similarly, no opportunity has been given for the Inuit to contribute in the decision-making process about possible tanker staging areas.

Finally, there is no consultation by the Government with the Inuit 
as to the effect of acculturation through the impact of white society which inevitably accompanies such development. To put it more bluntly, there is no consultation with the Inuit in the present process of colonization.

The changes taking place in the North have a profound influence upon the lifestyle and culture of the more than 13,000 Inuit in the North. There should be concern on the part of all Canadians as to the civilization of the Inuit which may suffer greatly, and indeed, perhaps vanish due to the impact of development of the North.

More than any other group in the western world, the Inuit live as an integral part of their natural environment. Perhaps they live a harsh life by the values of southern Canadians, but what right do others have to impose their values as being superior? The Inuit have a superbly functional civilization which is in jeopardy. They deserve the thoughtfulness of participating in the decisions affecting that civilization; they deserve the opportunity of making their views known; and, they deserve the right to be able to make proposals to ameliorate so far as reasonably possible the disadvantages of development.

The culture of the Inuit is related to the land base and has been from time immemorial. The Inuit therefore have the greatest stake of all Canadians in the protection of the environment of the North and the maintenance of the land base. Not only is development affecting the physical location of the Inuit as well as their livelihood, but it is affecting their cultural existence with the result that their very self-identity is in jeopardy. The Inuit have lived successfully as part of their environment for a very long time and have lived an energetic, rigorous, self-reliant and rewarding life, with immense pride resulting from such independence. Perhaps this is why the Inuit have always been such a truly happy people.

The existing policy of the Government is limited to attempting to gain employment opportunities for the Inuit through development and exploration activities. Apart from the fact that there seem to be relatively few such employment opportunities in all events, ${ }^{42}$ there is once again no consultation with the Inuit as to the possible ways in which employment opportunities might develop, or regarding unfair practices on the part of employers, etc.

Implicit in present government policy is the value judgment (albeit unintentional and unconscious, but more destructive because it is not realized) that the Inuit, and their views, count for very little if anything at all in the development taking place in the North. Present government policy is just as paternalistic as the historical policy which has been perpetuated in respect to the Indian people in southern Canada.

The present government policy toward the Inuit is further evidenced by Government documents. For example, the third draft of a Government

'2 James Woodford states in his recent book, The Violated Vision: The Rape of Canada's North 16 (1972):

At the January 1970 session of the Council of the Northwest Territories, Councillor Duncan Pryde revealed that although the government had invested nine million dollars in the Panarctic venture, only six Eskimos and no other territorial residents had been employed. In answer to a question in the House of Commons, Northern Development Parliament Secretary Russell C. Honey reported that only four Eskimos were employed by Panarctic's contractors as labourers at the rate of $\$ 1.75$ per hour-less than half the going rate in Toronto.

Similarly, Peter J. Usher in vol. 3 of his study, The Bankslanders: Economy and Ecology of a Frontier Trapping Community 47 (Information Canada, Ottawa, 1971) reports that the oil companies who were involved in exploration work on Banks Island offered the Bankslanders $\$ 1.67$ per hour for labouring jobs. The prevailing government rate for such work in the settlements was $\$ 3.12$ and, moreover, the Bankslanders' average earnings from trapping are very similar to this rate if converted to a standard hourly basis. 
document with the title Sample Dialogue to Articulate with Inuit, to be used by the recently created information team of the Government travelling about the North advising the Inuit as to what is taking place, states that the advantages of exploration are (1) jobs, and (2) lower prices for groceries and supplies. Apart from ignoring the fact that the Inuit had "jobs" until the arrival of white society with its form of "development", the document implicitly proceeds upon the assumption that the white man's "jobs" and possible ancillary benefits outweigh the loss of Inuit identity (which is not even discussed!) and traditional way of life. Nor can the document rationalize development on the basis that the Inuit use metals in tools, etc., oil for skidoos, and that royalties help pay for schools, etc. Although there may be some indirect benefit to the Inuit in this regard, as to other Canadians, it is only the Inuit who bears the cost of a significant loss or extinguishment to his heritage and identity!

Further, in respect to the problems pertaining to the environment and the need for protection thereof because of the possible harmful effects of exploration, the document says "we will see that this does not happen any more than is necessary" [emphasis added]. The present policy is that all decisions will be made paternalistically by the government without prior consultation!

\section{THE POSITION OF THE GOVERNMENT}

The Government issued its White Paper on Indian Policy in June, 1969 , and set forth, as one of the six basic requirements to afford Indians "full and equal participation in the cultural, social, economic and political life in Canada", that "lawful obligations be recognized". Then, within a few paragraphs the Government indicated that it had decided unilaterally (1) which obligations are lawful, and (2) even amongst these lawful obligations, which ones the Government will choose to recognize.

Thus, hunting and fishing rights became simply temporary privileges, the Government stating that it "is prepared to allow [treaty Indians] transitional free hunting of migratory birds under the Migratory Birds Convention Act and Regulations".

The White Paper also called for the appointment of a Commissioner to "inquire into and report upon how claims arising in respect of the performance of ... treaties ... entered into by ... the Indians and the Crown, and the administration of lands and moneys ... for the benefit of Indians may be adjudicated." 43 The Commissioner's role, therefore, would not be to deal with aboriginal rights generally, but simply to consider appropriate methods of adjudicating claims arising from treaties and the administration of lands and monies. The exclusion of the consideration of aboriginal rights in the terms of reference of the Commissioner was consistent with the Federal Government's view expressed in the White Paper that "aboriginal claims to land . . . are so general and undefined that it is not realistic to think of them as specific claims capable of remedy ..." Indeed, Prime Minister Trudeau had unilaterally stated that the Federal Government will not recognize such rights. In a speech in August of 1969 in British Columbia, the Prime Minister commented:

But aboriginal rights, this really means saying, 'We were here before you. You came

\footnotetext{
${ }^{43}$ Much of the following is taken from Native Rights in Canada, supra, n.1 at 263-64 [citations omitted]
} 
and you took the land from us and perhaps you cheated us by giving us some worthless things in return for vast expanses of land and we want to reopen this question. We want you to preserve our aboriginal rights and to restore them to us.' And our answer-it may not be the right one and may not be one which is accepted, but it will be up to all of you people to make your minds up and to choose for or against it and to discuss with the Indians-our answer is ' $n o$ '.

As a result, when the Commissioner, Dr. Lloyd Barber, Vice-President of the University of Saskatchewan, was appointed in December of 1969, his terms of reference were very restrictive. The Committee of the Privy Council, in making the appointment, based their decision on a report stating:

That many Indian people continue to feel aggrieved about matters arising out of the transactions between them and the other people of Canada during the settlement of Canada and the administration of certain of the Indians' affairs by the Government of Canada: That these grievances are put forward in the form of claims in respect of:

(a) the occupation of land by others without the prior and formal agreement thereto of the Indians using the land,

(b) the performance of the terms of treaties and agreements formally entered into by representatives of the Indians and the Crown, and

(c) the administration of moneys and lands pursuant to schemes established by legislation for the benefit of the Indians:

That is essential to the public interest and to the future of Indian Canadians to alleviate these grievances in a definitive way that is just, in our time, for all Canadians.

Following the recommendations of the report, the Committee of the Privy Council appointed Dr. Barber under Part I of the Inquiries Act empowering him "to consult with authorized representatives of the Indians" and,

1. To receive and study the grievances arising in respect of:

(a) the performance of the terms of treaties and agreements formally entered into by representatives of the Indians and the Crown, and

(b) the administration of moneys and lands pursuant to schemes established by legislation for the benefit of the Indians,

2. To recommend measures to be taken by the Government of Canada to provide for the adjudication of the claims received that he considers can be demonstrated to require special action in relation to any group or groups of Indians, and

3. To advise as to categories of claims that, in his judgment, ought to be referred to the courts or to any special quasi-judicial or administrative bodies that he recommends as being desirable for adjudication of specific awards.

Only methods of adjudication, therefore, for very limited classes of claims were to be investigated by Dr. Barber while consideration of claims based upon aboriginal title were excluded. The rationalization given for this by the Committee was that the assertion of grievances based upon aboriginal title "is so general and undefined that it cannot be settled except by a policy to enable Indians to participate fully as members of the Canadian community, ..." while those claims which are to be studied "can be related to accepted Canadian juridical concepts and are likely susceptible of assessment independent of those party to the grievances."

Understandably, the Indian people regarded this exclusion as arbitrary and unacceptable. Moreover, it was an illogical exclusion as the Commissioner could inquire into performance of the terms of the treaties 
but was precluded from considering the very basis upon which the Indians entered into the treaties and thereby agreed, as expressed in the treaties, to "cede, release, surrender and yield up" their lands.

However, more recent events have been encouraging. As the result of representations made by the National Indian Brotherhood, the Prime Minister stated to the Commissioner in August, 1971, that the Federal Government would not object to the Commissioner receiving "presentations on any and all subjects concerning rights and grievances which authorized representatives of the Indian people may wish to bring to him".

A remaining question is whether the Commissioner's terms of reference include a consideration of Inuit claims. The language of his terms of reference speaks only of the "Indian" people. However, as mentioned, there has been an expansion of matters for consideration by the Commissioner beyond treaty rights to aboriginal rights. With an acceptance of that interpretation given to the term "Indian" as used in s. 91(24) of the British North America Act (i.e., as encompassing all aboriginals) as also applying to the term "Indian" in the Commissioner's terms of reference, the Commissioner could hear submissions in respect to Inuit claims.

Further encouragement can be taken from Mr. Jean Chrétien's remarks of March 28, 1972, introducing a Report to the Standing Committee on Indian Affairs and Northern Development:

[W] are ready to discuss ... treaty claims [of the Indians of the Northwest Territories] or other grievances whenever they are ready to do so, whether they are raised with the Indian Claims Commissioner or with me. We welcome the attention that the Indian and more recently the Eskimo people are giving to these matters ...

\section{THE ALASKA NATIVE CLAIMS SETTLEMENT ACT}

On December 18, 1971, President Nixon signed into law one of the most imaginative pieces of legislation in American history-the Alaska Native Claims Settlement Act. 44 This resulted from approximately four years of consideration. However, time was on the side of the native peoples of Alaska as the United States Government had instituted a general land freeze after objections by the native peoples in 1966.

This legislation serves as a dramatic reminder that the United States, with the same common British heritage as Canada, continues to recognize aboriginal rights and claims. Moreover, it offers an important model for Canada in resolving many of the problems in the changing North. that:45

Apart from the straightforward declaration of policy by Congress

[T]here is an immediate need for a fair and just settlement of all claims by Natives and Native groups of Alaska, based on aboriginal land claims ...

Congress viewed the need for settlement as an opportunity for social change, as it was also declared that: ${ }^{46}$

[T]he settlement should be accomplished rapidly, with certainty, in conformity with the real economic and social needs of Natives, without litigation, with maximum participation by Natives in decisions affecting their rights and property, without establishing any permanent racially defined institutions, rights, privileges, or obliga-

485 Stat. 688, Public Law 92-203.

is Id. at $8.2(a)$.

4 Id. at 8. 2(b). 
tions, without creating a reservation system or lengthy wardship or trusteeship, and without adding to the categories of property and institutions enjoying special tax privileges or to the legislation establishing special relationships between the United States Government and the State of Alaska...

The Alaska settlement, very briefly, provides that the 55,000 natives of Alaska (any citizen of $1 / 4$ or more Alaska native blood or who, and a parent of whom, is recognized as an Alaskan native by a native village) will receive $\$ 962.5$ million, together with full title to 40 million acres of land to be selected by the approximately 205 native village corporations and 12 or 13 native regional corporations to be set up.

Some \$462.5 million will flow into an Alaska Native Fund over 11 years, together with up to $\$ 500$ million in royalties from resource development in Alaska. These monies (in total, almost $\$ 1$ billion) will be paid out of the Fund to the Regional corporations where they will be used as the shareholders decide, with at least-minimum percentages flowing through to the individual shareholders (10\% for the first 5 years) and the village corporation (at least $45 \%$ for the first 5 years and $50 \%$ thereafter). Moreover, the Regional corporations will share amongst each other $70 \%$ of the revenues from the development of the lands held by each of them.

There is a withdrawal of public land from development until selection of the 40 million acres by the Village and Regional corporations. The Villages will select up to 22 million acres, and receive title to the subsurface rights, as well as full title to another 16 million acres, in a checkerboard pattern, surrounding the lands of the Village corporations. A further 2 million acres is allocated to cover miscellaneous claims.

There is a tax exemption on benefits received under the settlement, other than income through the investment of benefits. Lands not leased or developed are free of all property taxes for 20 years. Revenues derived from the use of properties are taxable.

The corporations, monies and lands, will be controlled solely by the native shareholders, who cannot transfer their shares for 20 years. After that time the shares are held just as shares of any ordinary corporation.

A Joint Federal-State Land Use Planning Commission is established by the legislation to make recommendations in respect to all major public land use questions in Alaska. At least one member of this ten member Commission must be a native person.

Finally, the native peoples of Alaska may still receive additional benefits through protection of subsistence needs and requirements by the Secretary of the Interior closing appropriate public lands to entry by non-residents when the subsistence resources are threatened or in limited supply.

Most importantly, the Alaska Native Claims Settlement Act was the result of a process of full consultation with the native peoples. Favourable approval was given by the Alaska Federation of Natives to the final settlement.

It is important to realize that the legislation represents an acceptable adjustment of conflicting interests. If native claims had gone before the courts, the award may have been either higher or lower than the money value of the settlement. The settlement took into account that not more than a given amount was acceptable to the federal Treasury, while at the same time not less than a given amount would constitute both a 
fair settlement and also meet the needs of the native people. Moreover, the interests of non-natives had to be considered. The result was a solution acceptable to all.

The Alaska Native Claims Settlement Act therefore represents imaginative social policy within the context of American law which has always recognized aboriginal rights. The settlement of claims based upon aboriginal rights is being utilized as a unique opportunity for the structuring of a new relationship between native and non-native society, within the context of a rapidly changing Alaska.

\section{SUMMARY 47}

The native peoples are profoundly discontented with the Federal Government's attitude towards native rights. While it is within the prerogative of the Government to reject aboriginal and treaty rights, it is beyond the power of the current Government of Canada to simply deny history. Native rights have a four hundred year history in international law and have been part of the common and statutory law of British North American and of Canada for well over two centuries. Rights which find their derivation in such a rich history cannot be easily ignored.

The important issue is how to settle these outstanding claims in the North in a manner which is acceptable to all.

The least acceptable way for settling native claims is through litigation. Litigation is expensive, time-consuming, and abounds with technical uncertainties. But the decision whether to pursue litigation is really not in the hands of the native peoples for the choice ultimately lies with the Federal Government. If the Government enters into discussions with the native peoples and a satisfactory means of settling native claims is achieved, the need for litigation will diminish. If this does not happen, native peoples will have little alternative but to seek fulfillment of their ancient rights through the judicial process. However, the path of litigation is very unsatisfactory. First, if the native peoples lose, it will not redress their grievances because of their continuing moral claims based upon the undeniable events of Canadian history. There will be a continuing clamour for a fair and equitable political solution. Secondly, if the native peoples are successful, a legislative solution will remain necessary. The complexities of aboriginal rights and claims, and an adjustment of the various conflicts of interests, can only properly be resolved through a legislative solution, similar to that in Alaska.

The Federal Government has often advanced the superficially plausible argument that aboriginal and treaty rights are of no real consequence in today's world. Rather, it has argued, the important issues are the economic, social and educational problems of the native peoples, and it is these latter concerns to which native peoples, the public, and the Government should direct their collective efforts.

Paradoxically, it is the very denial of aboriginal and treaty rights by the Government that frustrates this goal, for there cannot be the requisite trust and willingness on the part of native peoples to enter into a meaningful dialogue while the Government continues to abrogate the fundamental rights of the native populace.

The second, and equally important reason for the recognition of

47 Much of this summary is adapted from Native Rights in Canada, supra, n. 1 at 275, 279-80 [citations omitted]. 
aboriginal rights is that this is the only truly effective, and, in the long run, least costly way of meeting the economic and social needs of the native peoples. The provision of monies to those who are asked to give up their ancient lands not as a handout or welfare (with all the debilitating consequences which such payments frequently engender), but as compensation for the loss of basic and valuable rights. The use of such compensatory funds in the context of native development corporations is being employed in Alaska. The native peoples of Alaska have the opportunity of maintaining their traditional way of life and culture and at the same time have the opportunity and means of participating in the development of Alaska. This mode of solution for Canada would represent a complete reversal of the historical policy of paternalism and assimilation.

A settlement similar to that in Alaska would not only have obvious sociothe policy which is most reasonable from the standpoint of economics. Although the initial cost of a settlement might appear to be large, it is insignificant when compared with the long range cost of welfare programs and a continuation of the policy of paternalism together with its massive bureaucracy. Finally, a settlement of aboriginal claims, as in Alaska, can take place within a context of facilitating the interests of all Canadians in imaginative land use planning in the North.

It is only through the enhancement of pride and self-identify that a people can achieve self-recognition and thereby maximize their contribution to society at large. Social and educational development is best achieved by letting those who are to receive the benefits of any given development program actually manage the program themselves. This crucial fact has already been recognized in those nations, such as Mexico, and Greenland, which are utilizing native development programs.

The immediate recognition of aboriginal rights would afford the opportunity to achieve a new and universally desired social policy in the North. The concept of a fair and equitable legislative solution, negotiated in consultation with the native peoples, is both realistic and consistent with the Canadian sense of justice. It would provide the native peoples of the North the position that is rightfully theirs in the cultural pluralism of the Canadian mosaic.

\section{APPENDIX-PART I}

The Hawthorn-Tremblay Report, A Survey of the Contemporary Indians of Canada, Vol. I, Indian Affairs Branch, Ottawa, 1966 at 163-64, provides some very broad and crude comparisons in respect of government spending on native peoples and non-native people. In 1964 the budget of the Indian Affairs Branch was approximately $\$ 60$ million or $\$ 300$ for every status Indian. In addition there must be added $\$ 20$ per Indian for Health Services. By comparison, in the same year the budget of the Federal Government was $\$ 6,550$ million, including $\$ 3,042$ million for goods and services, $\$ 2,235$ million for transfer payments, $\$ 995$ million for interest on bonded indebtedness and $\$ 278$ for subsidies. Provincial and Local expenditures in these categories were, respectively, \$5,565 million, $\$ 1,924$ million, $\$ 537$ million (this figure is incorrectly given in the Hawthorn-Tremblay Report as $\$ 937$ million), and $\$ 39$ million. All told, total government expenditure in 1964 amounted to approximately $\$ 14,615$ million for a population of 19.4 million people. This works out to about $\$ 750$ per capita as compared to the Indian Affairs Branch's spending of about $\$ 320$ per status Indian, a rate of more than two to one. Fidler, supra, $\mathbf{n}$. 23, at 3 , points out that by 1967 the per capita spending on each status Indian has risen to approximately $\$ 530$ but this figure is still far below government spending on non-native people for 1964 . 
Applying the above analysis to recent years we find the following figures:

Total Government Expenditures (in millions \$)*

1968

1969

1970

Provincial
6,057
6,784
8,176

Local

6,778

7,610

Hospitals
1,796
1,973
2,178

Pension

15

51

104
Total

23,695

26,385

29,967

Federal spending on native peoples (status Indians, and Inuit) during these years for the following categories (in million \$) are:

\section{Indian Affairs Programs}

Education

Health

Housing

Welfare

Roads

TOTAL

* From The National Finances 1968-69 (Canadian Tax Foundation, Toronto, 1968).

** From The National Finances 1969-70 (Canadian Tax Foundation, Toronto, 1969). *** From The National Finances 1970-71 (Canadian Tax Foundation, Toronto, 1970).

For the three years given, the per capita spending of all governments for each non-native person is approximately $\$ 1,197, \$ 1,250$, and $\$ 1,387$ respectively, based on population figures of 19.8 million in 1968, 21.1 million in 1969 and 21.6 million in 1970. By comparison, the amounts spent on status Indians plus Inuit, in each of those years is $\$ 654, \$ 711$, and $\$ 812$ respectively.

It should be noted, as the Hawthorn-Tremblay Report emphasizes, that these rather crude comparisons do not present an accurate picture of government spending. Defense expenditures alone account for almost two billion dollars in the figures per year and as such are a charge against the country as a whole. It is likely, however, that native peoples, because of their location and employment position, get little benefit either directly or indirectly from these expenditures as far as jobs and income are concerned. The same can also be said for other items, such as foreign trade.

Another area to which similar considerations apply is that of transfer payments. Native peoples are benefitting from such items as family allowances, old age security and pension payments which are made over and above expenditures by the Department of Indian Affairs and Northern Development. Moreover, the figures under health expenditures do not include all payments in respect of native peoples. The figures given represent payments for such items as sewage disposal and water systems. Actual health expenditures are part of regular government spending in the Department of National Health and Welfare. As a result this further distorts the comparability of the above per capita spending figures. Finally, there are many provincially and municipally funded projects from which native peoples would benefit such as roads, conservation, law enforcement, and development of natural resources.

Nonetheless, the overall picture provided by these figures indicates a marked difference in benefits through government spending accruing to the non-native sector of the Canadian populace in contrast with the native peoples sector.

\section{APPENDIX-PART II}

The Department of Indian Affairs and Northern Development budget estimates are as follows in respect of Northern Development Programs (in millions \$):

Administration

$\begin{array}{rcc}1969-70^{*} & 1970-71^{* *} & 1971-72^{* * *} \\ 6.5 & 7.5 & 8.8 \\ 11.4 & 11.0 & 15.1 \\ 7.1 & 14.4 & 16.5\end{array}$

* From The National Finances 1969-70, supra, n. 24 at 181.

** From The National Finances 1970-71, supra, n. 24 at 196.

*** From The National Finances 1971-72, supra, n. 24 at 225. 
The funds for administration cover executive activity including the offices and staffs of the Minister,Deputy and the Assistant Deputies; advisory services including legal, information, financial and management, personnel, program management evaluation and secretarial services; and, technical services including engineering and architectural service and functional direction of material management. 